\title{
ASPEKTE VAN GEN. 1-3 EN DIE NATUURWETENSKAPPE
}

\author{
J.L. Helberg \\ Departement Teologie, PU vir $\mathrm{CHO}$
}

\section{SUMMARY}

This article wishes, from the angle of the subject of Revelation History, to offer thoughts and ideas about aspects touching on the shared issues of the various disciplines. The special nature of the material and of the purpose of Genesis $1 \mathrm{ff}$. does not necessarily imply that a closed succession of days is meant. God is the Creator and the Ruler over all things, and has a historical destiny for the earth. Man is the steward over creation, has an ecological task and is in that responsible to God. He is in a communational relation to God, and is free from the enslavement of a combination of natural and spiritual forces. There is a special relation between man and beast, but there is no question of a communational relation there, only with God, of whom man is the image. Sin corrupted the relation between man and creation, but Genesis 2, 3 already stand in the sign of the expectation of restoration. There is a universal basis for the practice of scholarship, and at the same time the shaping demand is that knowledge begins with the service of God.

\section{INLEIDING}

1.1 Hierdie artikel handel nie oor skepping en/of evolusie nie. Daaroor is in die afgelope jare, en in besonder in die jongste verlede, baie gepraat en geskryf. Hier kan verwys word na Manten (1959/1984) wat beweer dat die skeppingsgeskiedenis nie letterlike geskiedenis is nie, maar terugwaarts gerigte profesic van die heilsgeskiedenis. Du Toit (1968) staan ' $n$ benadering van progressiewe kreasie voor. Die debat oor Koers 53(1) 1988 
evolusionisme en kreasionisme duur voort. In hierdie verband kan verwys word na die artikel van Schuurman (1980) en na din standpunte van die voorstanders van die onderskeie bonaderings ondor rodaksie van Bul ke (1984). Verder kan verwys word na onlangse publikasies van Leith (1984) en van Jordaan en Loots (1984) - om maar enkeles te noem.

Die gedagtes wat hier uitgespreek word, kom uit die vakgebied Openbaringsgeskiedenis. Dit handel oor wat God deur sy Woord geopenbaar het, nie oor wat God nie so geopenbaar het nie. Daaron word hierdie artikel tot dié vakrigting beperk.

1.2 Om wetenskaplik navorsing te doen en onderrig te gee, vereis dat ook oor die grense van die onderskeie vakgebiede heen gesprek gevoer moet word. Die naam "universiteit" hou verband met universum en dui aan dat elke vakgebied sy veld van ondersoek binne die universele opset van die hele wetenskap wil beoefen.

In die lig hiervan word hier enkele gedagtes en gedagtelyne gegee onr aspekte wat die gemeenskaplike terrein van die betrokke vakgebiede kan raak. Die doel is nie om vir natuurwetenskaplike probleme antwoorde te gee nie, laat staan nog voorskrifte.

1.3 Die doel van die Bybel, en dus ook van Gen, 2-3, is nie orn 'n wetenskaplike handboek of wetenskaplike voorskifif te bied nie. Die probleme oor die regte verklaring van hierdie gedeelte dateer ook nie vanaf die tyd dat die natuurwetenskappe werklik begin ontwikkel het, of vandat die leer van evolusie op die toneel verskyn het nie. Reeds in die vierde eeu het die kerkvader Augustinus beweer dat Gen. 1 nie letterlik opgevat moet word nie. Augustinus het geleer dat God alle dinge in die begin tegelyk geskep het deurdat die Goddelike idees omgesit is in kieme en oorsake. Dié het in die tyd ontwikkel en was aanvanklik meesal nog slegs in potensie, in konkrete kiemvorm (Manten 1984:392,3; Du Toit 1968:177).

Dit is belangrik dat daar by die verklaring van Gen. 1-3 onderskei moet word tussen wat die Bybel self wil sé en wat teolö̈ sè, net soos daar onderskei moet word tussen wat die natuur is of $s \dot{e}$ en wat natuurwetenskaplikes daarvan sè. Wat meer is, selfs die algrmeen -40 - 
gangbare verklaring van 'n Skrifgedeelte deur teoloë kan verkeerd wees, soos die reaksie teenoor Galileo bewys het. Daarom moet altyd weer opnuut en onbevange na die Bybel self en na die skepping of natuur gekyk word.

1.4 Vandag word daar meer genuanseerd oor die begrip "onbevange" gedink en geskryf as 'n paar dekades gelede. Toe was daar dikwels 'n groot vertroue in wetenskaplike onbevangenheid en objektiwiteit, en daarmee saam 'n onbevange en objektiewe wetenskap. Vandag word egter meer algemeen besef dat elke mens, en daarmee elke wetenskaplike, sy waarnemings en afleidings vanuit bepaalde gesigspunte, bepaalde voorveronderstellings, doen. Vanuit hierdie besef word alle wetenskappe, insluitende die teologie, opgeroep om weereens krities te gaan kyk na alle aspekte van sy wetenskapsbeoefening, ook na dié dinge wat sonder meer as seker en korrek aanvaar is. Hierdie benadering kan te ver gevoer word en uitloop op relativisme en selfs nihilisme. Hier kan nie op die kwessie van wetenskaplike uitgangspunte en metodes ingegaan word nie. (Vir 'n oriëntering en literatuur daaroor, vgl. bv. Duvenage 1982, 1985; Mouton 1985).

Die nuwe verwikkelinge bevestig in elk geval wat die Skrif leer, naamlik dat menslike en wetenskaplike feilbaarheid besef moet word en dat benaderings daarom voortdurend gereformeer moet word. Dit onderstreep die noodsaaklikheid van gedagtewisseling binne die eie vakrigtings sowel as tussen verskillende vakrigtings, en skep 'n vrugbare atmosfeer daarvoor.

1.5 Die basiese probleem rakende die verklaring van Gen. 1-3 raak seker nie die ouderdom van die aarde nie maar dinge soos die wese en aard van die mens, sy verhouding tot God, sy verhouding tot die natuur en tot ander skepsele, die sondigheid van die mens en die aard van die sonde. In hierdie verband is die verklaring van eenstemmigheid deur sewe wetenskaplikes, voorstanders van spesiale skepping en van teïstiese evolusie onderskeidelik, belangrik (Burke 1984:261). Dit lui soos volg: "There is unqualified agreement ... that God is the sovereign creator of all things, that he created ex nihilo, and whereas the whole of creation was 'very good,' man is not very good. He is a fallen being, sinful and nol improving morally by any evolutionary process. There is no built-in 
process of moral improvement in God's world and all our authors are in unqualified opposition to attempts to derive a philosophy of progress from science or a reduction of man's sin to anything less than rebellion against God. Sin is not a relic of animal ancestry."

Dit gaan in Genesis om die algehele heerskappy van God oor alles. Hy staan veral in 'n persoonlike verhouding tot die mens, die mens wat die kroon van die skepping is en tewens 'n totaal sondige wese. Met persoonlike verhouding word bedoel 'n indiwiduele verhouding, warin die mens nie as 'n blote onderdeel van 'n groep geay word nie, tegelykertyd 'n verhouding van gemeenskap, in onderskeiding van ' $n$ bloot saaklike verhouding, en tegelykertyd 'n verhouding waarin daar ruimte is vir 'n verbondenheid aan andere, in onderskeiding van 'n indiwidualistiese verhouding. Ook die res van die skepping of natur word deur die mens se sondigheid geraak. Die mens word deur God se lewewekkende Goddelike optrede verlos en dit hang saam met bekering by die mens. Die skepping of natur het ' $n$ band met die geskiedenis. Verder leer Genesis dat God se Woord 'n belangrike rol vervul in die totstandkoming van die natuur, en ook in die verklaring darvan.

Hieronder sal nou op die volgende sake ingegaan word:

Enkele uitgangspunte vir die verklaring van Gen. 1-3.

Wat wil Genesis 1 openbaar?

Die Bybelse openbaring is bevrydend.

Skepping en sonde.

Die taak wat opgelè is. 
2. ENKELE UITGANGSPUNTE VIR DIE VERKLARING VAN GEN. 1-3.

2.1 Om 'n Skrifgedeelte te kan verklaar, is kennis van die oorspronklike lesers en hulte kultuurhistoriese agtergrond belangrik. Al handel Gen. 1-3 oor die ontstaan van die aarde, dateer dié Skrifgedeelte tog nie uit daardie tyd self nie. In sy huidige vorm het dit eers in die tyd van Moses of selfs heelwat later ontstaan. Wie die bepaalde Skrifgedeelte verklaar, moet homself die vraag afvra hoe die destydse lesers dit sou verstaan. Dit is in die eerste plek vir hulle geskryf. Kennis van die lesers se omstandighede kan byvoorbeeld help om teenstellings met heidense opvattings van daardie tyd raak te sien en die oogmerk van die skrywer met sekere stellings duideliker vas te stel. Genesis 1-3 gee nie bloot tydlose stellings of waarhede nie. Dit praat nie ' $n$ taal wat die mense van die skrywer se tyd nie sou verstaan het nie en in huidige wetenskaplike benaderingswyse uitgedruk sou wees nie.

$2.2 \mathrm{Om}$ ' $\mathrm{n}$ Skrifgedeelte te kan verklaar, moet ook die aard van die stof of die soort literatuur, vasgestel word. Genesis 1 het enersyds'n historiese opset: daar is ' $n$ omlyning (aand-móre). 'n opeenvolging en selfs 'n numering van dae (eerste, tweede, ens.). Verder word die tipiese verhaaltrant gebruik: "en toe ... en toe ...". Dit alles pleit vir 'n historiese, letterlike bedoeling. Andersyds is die opset baie skematies, met vaste refreine: "toe het God gesê...", "So het dit gebeur," "En God het gesien dit is goed." Hierdie feit maan tot versigtigheid. Genesis 1 moet nie sonder meer as gewoon letterlike beskrywing opgeneem en daaruit enkelvoudige afleidings gemaak word nie. Dit geld ook vir Gen. 2 en 3. In Gen. 3:21 staan dat God vir die mens en sy vrou velklere gemaak het en hulle dit aangetrek het. Dit kan moeilik gewoon letterlik verstaan word. Daarby is dit die enigste plek in die Skrif waar gesê word dat God kultuurgoedere gemaak het. Ons het hier dus blykbaar met 'n unieke manier van uitdrukking te doen. Hierdie feit dat 'n besondere manier van uitdrukking gebruik word, moet ook by die verklaring van die res van Gen, 1-3 in gedagte gehou word.

2.3 Die basis vir verklaring van die Skrif kan nie die eie logika, of die dissipline vir verklaring van letterkunde of geskiedenis, natuurwetenskap of wat ookal wees nie, al is daar belangrike ooreenkomste ell al kan $-43-$ 
Skrifverklaring onk by die ander dissiplines leer. Om 'n Skrifgedestle reg te verklaar, moet met ander Skrifgedectes rekening gehou word. By alle verskeidenheid is die Skrif in ecnlieid en is hy sy aie verlilanmer (vgl. ook Helberg, 1983:69, 70).

Die verklaring van die begrip "dag" in Gen. I moet rekening hou met die motivering van die gebod oor die rusdag in Eks. 20:8-11. Die gebod om ses dae te werk maar die sewende dag te rus word dár gebaseer op God se skeppingswerksaamheid van ses dae en sy rus op die sewende dag. Daar is egter ook ander Skrifgedeeltes wat uit "n heeltemal ander hoek lig op die begrip "dag" in Gen. 1 laat val. Hier kan verwys word na die geslagsregister in Gen. 11:10 e.v. In Lukas 3 kom dieselfde geslagsregister voor. Wanneer dié twee registers met mekaar vergelyk word, blyk dit dat Gen. 11:10 e.v. minstens een geslag oorslaan. Dit is die geslag Kenan, tussen Arpaksad en Selag $(=$ Sala) (Luk. 3:36). Uit die geslagsregister se formulering self lyk dit egter onmoontlik dat daar een geslag uitgelaat kon wees, want die geslagte ivord in geslote opvolgingslyn gegee. Die geslagsregister sè hoe oud Arpaksad was toe Selag gebore is ("Toe Arpaksad 35 was, het hy die vader geword van Selag") (Gen. 11:12). Daar kan nou 'n stappie verder soos volg geredeneer word: die vergelyking tussen Gen. 11 en Luk 3 wys dat daar 'n geslag oorgeslaan is, of, beter gestel, minstens een. Daar hestaan trouens ook 'n moontlikheid dat Gen. 11 en Luk. 3 hier albei meer as een oorgeslaan het. Daar is verder ' $n$ moontlikheid dat aibei geslagsregisters ook nog een of meer persone tussen die ander genoemdes weggelaat het.

Hierdie Skrifgedeeltes wys dat daar met die doel van díe skrywcr rekening gehou moet word. Die skrywer is nie in die doen en late van die geslagte of in hulle chronologiese besonderhede self geïteresserrd nie. Sy weergawe bedoel nie om 'n notarieel volledige beskrywing te gee nie, maar hy wil aantoon hoe Gód sé wérk voortgaan: deur die gralagle in die geskiedenis heen. As daar met hierdie doel rekening gehou word, mag dié gedeeltes andersyds ook nie as onhistories of onbetrouban beskou word nie. Dit gaan in die beskrywings om God se werksramhede? in bepaalde historiese geslagte, en die geskiedenis of geslagsregister is met die oog op hierdie bepaalde doel beskryf en geformuleer. 
Gen. 1-11 bevat dieselfde tipe stof len vorın die sogenaamde voorgeskiedenis). Daaron kan die geslagsregister in Gen. 11 lig werp op hoe die dae in Gen. 1 verstann moet word. Net so min as wat die geslagsregister in Gen. 11 ' geslute opvolying val geslagte of persone bedoel, hoewel dit in so 'n vorn geformuleer is, net so min hoef Gen. 1 in geslote opvolging van dae te bedoel, hoewel dit in so 'n vorm geformuleer is. Daar staan wel "Dit het aand geword en dit het mòre geword. Dit was die eerste dag ... tweede dag .... derde dag ..., ens." Tog is dit moontlik dat die skrywer nie wil sê dat God se skeppingswerk net ses dae geduur het nie, mar dat sy skeppingswerk wel ses dae kardinale konsentriesepunte of ingrypingspunte gehad het. Op daardie dae het God se optrede dan besonderlik verband gehou met die uiteindelike doel van sy skeppingsoptrede. Hierdie doel is die persoonlike gemeenskap tussen God en mens, 'n gemeenskap waarin die mens God dien (Helberg, 1980:19). (Kyk vir ander verklarings van die dae in Gen. 1. Helberg, 1980:16-18; Du Toit, 1968:177-187. Vir verdere bespreking van die onderhawige en ander sake rakende ons onderwerp kan verklarings en kommentare soos die volgende geraadpleeg word: Weiss (1958), Aalders (1949), Marks (1971), Gispen (1966), Kline (1970), Kroeze (1967, 1974), Oosterhoff (1972), Ridderbos (1963), Calvyn (1981) en, meer tegnies van aard, Gispen (1974), Van Selms (1967), Von Rad (1963), Simpson (1952), Westermann (1974).)

Uit die voorgaande blyk dat Gen. 1 nie te enkelvoudig verklaar moet word nie. Die skeppingswerk van God is ' $n$ groot wonder. Dit kan nie in menslike taal en vir menslike begrip ten volle begryplik gemaak of geformuleer word nie. Die mens staan totaal oorweldig voor hierdie wonder, en kan eintlik slegs in verbasing daaroor praat, soos dit pragtig in Ps. 8 besing word: "Here, ons Here, hoe wonderbaar is u Naam oor die hele aarde ... kinders en suigelinge besing die magtige werk wat $U$ tot stand gebring het... As ek $u$ hemel aanskou, die werk van u vingers ... wat is die mens dan dat $U$ aan hom dink?" (vgl, ook 4.2). Die skepping van die mens in Gen, 1:1-2:3 en Gen. 2:4-25 byvoorbeeld vanuit heeltemal verskillende hoeke beskryf. (Vir die indeling Gen. 1:1-2:3 en 2:4.25 in plaas van 1:1-2:4a en 2:4b-25 vgl. Van Selns, 1967:47.) Elkeen wil 'n besondere aspek of situasie belig. Ferder as om Gen. 1 te enkelvoudig te verklaar, mont besef word dat die Skrif nie sê hoe alles presies in mekar steek nie. Daar moet veral na die res van die $-45-$ 
Skrifgegewens in die hoofstuk en daarbuite gekyk word, gegewens wal so belangrik is om die inens se verhouding tot God en die skopping of natuur te belig.

Voor daartoe oorgegaan word, moet daar met betrekking tot die wonderkarakter van God se skeppingswerk die volgende opgemerk word: Die problematiek van die wonder in die Gereformeerde teologie is besonder ingewikkeld en hang sam met die belydeniskarakter van die uitspraak soos in Ps. 8 gedoen. Die beperktheid van die menslike kennis vind enersyds in die twintigste eeuse wetenskap toenemend erkenning, ook in die natuurwetenskappe en die natuurfilosofie. Hier kan ook verwys word na die filosofie van die fisika soos dit by Von Weizsäcker (1974) tot uiting kom. Andersyds vereis dit ook gelowige erkenning van die betekenis van die wonder vir 'n christelike benadering in die wetenskap, insluitende die teologie. In hierdie verband kan verwys word na in eerste begin deur Diemer (1963:23-30, 77-85, 123-127).

\section{WAT WIL GENESIS 1 OPENBAAR?}

Genesis 1 wil nie sê dat daar 'n God is nie, net so min as wat hy wil sê dat daar 'n skepping, 'n natuur, is. Die bestaan van God en van die skepping word as 'n werklikheid aanvaar en daar word nie eens oor geredeneer nie. Die hele Skrif het hierdie benadering, trouens die Skrif stel dit so: Dit is 'n dwaas wat dink daar is geen God nie (Ps. 14:1). Genesis 1 wil veral verkondig dat God die Skepper en dic Regeerder is en dat Hy in 'n persoonlike verhouding met die melıs staan.

3.1 God is die Skepper van alle dinge. Hy is nie maar 'n oerkrag of 'n oermag nie. Wat ontstaan het, was nie 'n emanasie of nitvloeisel nit God, soos sommige panteistiese rigtings leer nie, maar 'n skeppingsdaad, die resultaat van God se wil, sy bevel: "Toe het God grse ..." Mierdie woorde kom as ' $n$ refrein in Gen. 1 voor en vergesel die verskillende skeppingsdade van God. Daar is 'n noue verbancl tussen skepping en woord. Psalm 33 stel dit soos volg: "Deur die woord van die llere is 
die hemele gemaak, deur sy bevel al die hemelliggame, ... want hy het gepraat en dit was so, lly het beveel en fit was daar" (Ps. 33:6,9). Psalm 19 lè 'n verband tussen natuus cll wrord. Aan rie beģin van die psalm word gesè hoe die liatuur on God getuig (19:1-7), daarla word die woord of wet van die Here besing (19:8 c.v.). Hiermee word duidelik gesê dat die natuur en die Bybel nie los van mekaar staan nie, maar dieselfde Skepper verkondig, ten diepste dieselfde woord, gedagtes en wysheid van God dra. Hierdie feit is belangrik in die beofening van wetenskap. Dit geld van teologiese wetenskap sowel as van natuurwetenskap.

God het "die hemel en die aarde," dit wil sé alle dinge, "geskep" (Gen. 1:1). Dit beteken dat Hy dit as iets heeltemal nuuts te voorskyn laat kom het (vgl. Eks. 34:10; Num, 16:30). Wat bestaan, is nie maar die gevolg of ontwikkeling van wat vroeër was nie, maar is die vrug van 'n direkte optrede van God. Alleen God kan skep. Die woord "skep" (bara) word in die Ou Testament nooit vir die werksaamheid van iemand anders as God gebruik nie (Helberg, 1980:12). God se skeppingswerk in Gen. $1: 1$ is dus ' $n$ skepping ex nihilo. Tereg aanvaar die ineeste eksegete dic Massoretiese teks wat van die vroegste tyd gevolg is en wat lui: "In die begin het God die hemel en die aarde geskep". Die alternatiewe vertaling vir Gen. 1:1 wat op 'n ander vokalisering van die Hebreeuse woord vir "skep" berus, (bero i.p.v. bara), word dus verwerp. Hierdie alternatiewe vertaling lui soos volg: "In die begin toe God die hemel en die aarde geskep het, was die aarde woes...". (letterlik: In die begin van die skep van God die hemel en die aarde). Volgens hierdie vertaling was die aarde reeds woes en leeg toe God begin skep het, en het lly slegs vorm daaraan gegee. So 'n opvatting is egter in stryd met die res van die Ou Testament warvolgens God dic absolute skepper van alles is (vgl. bv. Jes. 40:21,41:4; Spr. 8:22). Bogenoemde vertaling is onk in stryd met die gees en aksent van die hoofstuk self, want daarin is die werk van God telkens die hoofsaak on staan in die hoofsin, terwyl die vertaling God en sy werk in 'n bysin stal on 'n bysaak maak (Helberg, 1980:11).

Anders as by die ander nasies se beskouings is daar in Gell. 1 geen sprake van 'n stryd tussen gode wat tot die ontstaan van die skepping gelei het nie; ook nie van 'n stryd tussen God en gode nie. Daar is ook nie sprake van 'n stryd tussen God en bose magte nie. Die beskouings 
van Du Toit (1968:168) en Kroeze (1962) warvolgens "woes en leeg" en "wèreldvloed" (tohu, bohu, tehom) en duisternis met onlicilspellende demoniese magte verband hou, moet afgeuys word. Nerens in die hoofstuk is daar sprake van' $n$ mag of 'n inisiatief wat te-noor God staan nie. Die hoofstuk le inteendeel 'n swaar aksent darop dat God die enigste is wat alle inisiatief het; sy werk is ten volle effektief en word met onmiddellike gehoorsaamheid beantwoord: Telkens volg daar: "So het dit gebeur," en "En God het gesien dit is goed" (vgl. verder Helberg, 1980:12, 13).

Dit is wel waar dat die digterlike gedeeltes in die Ou restament soms by die nasies se mitologiese beskouings oor stryd met chaosmagte aansluit, bv. Leviatan en Ragab die seemonster. Genesis 1 is egter nie in digwerk nie en bowendien deel die Bybelse digters nie die mitologiese beskouings warby hulle aansluit nie, maar maak slegs vir hulle eie doel daarvan gebruik. Hierdie digterlike gedeeltes kan dus nie as motivering vir 'n stryd in Gen. 1:2 dien nie (vgl. ook Van Selus, 1967:44). Genesis 1:2 sè wel dat die aarde nog heeltemal onbewoonbaar was, maar maak nie " geestelik-kosmologiese, of teologies-kosmologiese wardcoordeel daaroor nie.

3.2 Genesis 1 leer dat God die Regeerder van alles is. Hy was nie net 'n Skepper nie, maar het ook in volle belieer van sy skepping, die natuur, gebly. Die Ou Testament ken dan ook nie 'n neutrale begrip natuur, wat min of meer onafhanklik en volgens eie wette bestaan, soos die moderne begrip natuur dikwels gesien word nie. Vir die Oll Testament staan die natuur in 'n lewende verhouding met God (vgl. bv Schunck, 1979:4()2)

Die regering van God is egter nie net 'n voortgaande skeppingswerk nie. Sy skeppingwerk is ná die sesdaagse skeppingsoptrede voltooi en afgesluit. Daarna volg sy rus. Daarmee is 'n duidelike onderskeid gemaak tussen skepping aan die een kant en die onderhoudende en reddende voorsorg aan die ander kant (Du Toit, 1968:190; Von Rad, 1963: 60).

God beheers die hele skepping. Dit geld van die ruimte: telkens word gesè dat Hy skeiding gemak het (tussen die aarde en dir hemelgewelf, 
tussen land en see, ens.). Dit geild onk van die tyd: Hy bepaal die clae van die week, ook gee Hy dic tydsaanduiders, soos die hemelliggane $(1: 3)$.

Alles is onder die volle heerskappy van God. Hy het alles georden. Daar is orde in die skepping. Hierdie feit is van groot belang vir die natuurwetenskap omdat die natuurwetenskap op hierdie orde, byvoorbeeld die wetmatigheid van die natuur, gebou word.

Genesis 1 leer verder dat alles nie maar deel is van 'n altyddurende sirkelgang soos die natuurgodsdienste geleer het nie. Die natuurgodsdienste kon in hulle benadering nie bokant die natuullike gang van dinge uitstyg nie, maar was daarin vasgevang soos in die ewigdurende siklus van die jaarseisoene. Genesis daarenteen verbind die skepping met die geskiedenis en maak darmee tegelykertyd die toekoms oop. Na die skeppingsberig word gesè: "Dit is die geskiedenis (toledot) van die hemel en die aarde" (Gen. 2:4). Die uitdrukking "toledot" kom dikwels in Gen. voor $(2: 4 ; 5 ; 1 ; 6: 9 ; 10: 1 ; 11: 10,27$; $25: 12,19 ; 36: 1,9 ; 37: 2)$, met wisselende betekenis, byvoorbeeld as stamboom en geslagte. Die gemeenskaplike element in die betekenisse is dat dit geskiedenis en voortgang aandui. Hier word meer as bloot geskiedenis aangedui, maar wel 'n nuwe begin in aansluiting by wat voorafgaan. Historiese lyne word getrek, van 'n begin na 'n eindpunt (llolwerda, 1971:12,13). Die verloop van sake in Genesis word verder ten nouste verbind met God se beloftes an Abraham, Isak en Jakob, beloftes wat in die toekoms vervul sal word (vgl. bv. Gen. 12:1-3; 15:17). Genesis roep dus toekomsverwagtings wakker. Vir die skepping. die aarde, is daar nie net in bestaan nie, maar ook in historiese bestemming.

3.3 Genesis 1 verkondig met groot nadruk dat God in 'n persoonlike verhouding tot die mens staan. In dic eerste plek word wel verkondig dat God alle mag liet on slat $\mathrm{Hy}$ die Skepper is wat in ' noue verhouding met die hele stoflike skepping staan. Genesis 1:1 word dan ook soms tereg 'n koninkiyksvers genonm: "In die begin het God die hemel en die aarde geskep." Hierdie vers moet dan egter nie geïsoleerd gesien word nie, inaar bimne die verband van din hoofstuk as geheel. Genesis 1:1 teken iets wat op daardie starlium nog onvolledig is. Daarom gep dit -49 . 
ook nog 'n onvolledige beeld van die koninkryk van God. Die volledige beeld is eers daar wanneer die mens geskep is. Dit blyk claaruit dat die hele hoofstuk afstuur op die skepping van ble mens on darin samtrek. Alleen by die skepping van die mens biriduslaag God met Homself: "Kom ons maak die mens" (1:26). Ná die ander skeppingsdade van God volg telkens: "En God het gesien dit is goed." Ná die skepping van die mens word egter gepraat van "baie goed" $(1: 31)$. Bowendien word die mens nie apart van die ander skepsele beoordeel nie. Daar staan: "toe het God gekyk na alles wat Hy gemaak het, en dit was baie goed" (1:31). Die mens is nie maar net nog een van die skepsele naas die ander nie, maar in hom word die skepping van al die ander in een punt saamgetrek. In die mens se bestaan vind hulle hulle ware sin en betekenis; dan is dinge nie meer net "goed" nie, maar dan is alles saam "baie goed". Dan voldoen hulle by uitnemendheid aan die doel wat God met hulle het (Helberg, 1980:20).

Die mens is dan ook aangestel as heerser oor die skepping $(1: 28)$. Hy is die kroon van God se skepping. Hy alleen is as beeld van God geskep. die verteenwoordiger van God $(1: 26-28)$, kind van God $(5: 1,3)$. Hy staan in ' $n$ eiesoortige verhouding met God on is die heerser van die skepping; tegelykertyd is hy volkome afhanklik van God en in diens van God. Die mens staan in 'n persoonlike verhouding met God, nie bloot in 'n groepsverhouding, 'n kollektiewe verhouding nin (vgl. ook Rom. 5:12 e.v; Blocher, 1984:164). By die diere is dit anders, volgens Gen. 1 handel God met hulle groepsgewys, volgens soorte of aard.

Die feit dat die mens heerser van die skepping is en drarin tegelykertyd onder heerskappy van God staan, is belangrik vir die beocfening van wetenskap. Die mens het die vryheid on wetenskap te beofen. Hy hoef nie voor die natuur te buig nie maar kan dit inteonseol onrlerwerp. Tegelykertyd mag hy nie sommer willekeurig teennor die natuul uptree en dit na hartelus eksploïteer en uitbuit nie. Hy is inteendeel verantwoording daarvoor verskuldig aan God. Hy het 'n ekologiese taak wat hy met verantwoordelikheid moet uitoefen. Die du Trstament bevat dan ook ekologiese bepalings, byvoorbeeld dat landnrye sctere tye nie gesaai of beplant mag word nie, mar moet rus (Lev. 25) 
God is ook nie net in die mens se grostrtike varlossing of in die verlossing van die mens op homself geinteressecril sulat die arede of die natuur in God se skeppingswerk of in sy niteindrslike doel weinig warrde het nie (vgl. ook Santmire, 1985: 190 e.v.). Inteendeel, in die vooralgaande besprekings is wel gesien dat die mens die kroon van die skepping is, maar tegelykertyd dat hy nie op homself staan of gewardeer word nie. Sy bestaan word saam met dié van die res van die skepping gewaardeer as "baie goed." Dit is nie toevallig dat die Bybel met die skeppingswerk van God begin nie (vgl. Helberg, 1983:77 e.v.). God se verhouding met die mensdom, die geskiedenis van verlossing, of wat ookal, alles moet gesien word teen die agtergrond van God se hoedanigheid as Skepper van hemel en aarde, sy werksaamheid aan die hele skepping ( $v$ gl. ook Westermann, 1974:241). God se seën aan die mens het juis te doen met sy stoflike lewe, veral vrugbarheid, en sy verhouding tot die hele stoflike skepping (Gen. 1:26-28).

Die Ou Testament verkondig vir die toekoms dan ook nie alleen 'n nuwe hemel nie, maar 'n nuwe hemel on 'n nuwe aarde, of, beter gestel, ' $n$ hernude hemel en aarde (vgl. Jes. 65:17-25). Oor wat dit alles vir die verhouding Bybel-ekologie beteken, kan hier nie verder gehandel word nie. Hier word volstaan deur daarop te wys dat die belangstelling hierin veral sedert die oliekrisis enkele jare gelede sterk opgeleef het. Verder kan verwys word na die artikel van steck (1978) en die boek van Santmire(1985). Daar moet verder op gewys word dat die Skrif nie in terme van teenstelling oor die geestelike en stoflike dinge ens. handel nie, maar ' $n$ integrale karakter het (Helberg, 1984).

\section{DIE BYBELSE OPENBARING IS BEVRYDEND}

4.1 Die Bybel is bevrydend vir die mens, nie verslawend nie. Dit staan in teenstelling tot die beskouing by ander oud-oosterse nasies met hulle natuurgodsdienste. By hulle was daar verslawing en onderwerping van die mens aan die natuur in plaas van beheersing daarvan. Verder was daar verslawing aan 'n kombinasie van natuur- en geestelike kragte, soos in die geloof dat mensoffers die gode se toorn sal laat help bedar. Dit 
alles het 'n verslawing aan die opvattings van presters en ander persone meegebring. Oris sou dit kon noem verslawing aan die nalg vall hulle "kerk."

Dit is nie toevallig dat Genesis nie die Godsvolk of die kerk prominent stel nie, maar die skepping, die geskiedenis van die mensdom en die lewe van die aartsvaders in die geheel. Die kerk is in wese die gelowiges, nie 'n georganiseerde struktuur nie. Laasgenoemde is wel nodig. mar is nie primèr nie. Die gelowiges, mense, is die kerk; hulle is nie dar vir die kerk nie.

4.2 Genesis 1 gee ' $n$ antwoord op die vraag na die plek van die mens op die groot aardbol en binne die grote kosmos. Is die mons maar ' $n$ verlore spikkeltjie in die ruimte en tyd? Die psalmdigter slamel die virag uit: "As ek u hemel aanskou, die werk van u vingers, die man en die sterre waaraan $U$ ' $n$ plek gegee het, wat is die mens dan dat $U$ aan hom dink?" (Ps. 8:4,5). Hierdie gedagte is so oorweldigend en bring die mens onder so ' $n$ diepe besef van sy nietigheid dat dit hom tot diepe depressie kan stem. Maar nee, Psalm 8 sê daar is " besondere verhouding tussen die mens en God die Skepper wat alle ruimte en tyd oorspan. Die mens is nie verlore in die grote skepping en natuur nie. maar sy bestaan het sin en doel: "Wat is die mens dan dat $U$ aan hom dink, die mensekind dat $U$ na hom omsien? $U$ het hom net 'n bietjie minder as 'n hemelse wese gemak en hoin met aansien en eer gekroon, $U$ laat hom heers oor die werke van $u$ hande, $U$ het alles adn Hom onderwerp: skape en beeste, alles; selfs die diere in die veld, die voëls in die lug, en die visse in die see wat die oseane deurkruis" (8:5-9). En die doel en resultat van dit alles? Daarvan getuig dic begin en einde, die omraming van die psalm: "Here, ons Here, hoe wonderbaar is u Naam oor die hele aarde!"

Die mens word in Ps. 8 en Gen. 1 geteken as 'n wese wat nie op dieselfde vlak as die dier staan nie. Daar bestaan wel 'n besondere omgang tussen die mens en die dier. Die beeld van die herder en sy stiape is die beeld van versorging, teerheid en trou (Ps. 23). Tog is daal gem sprake van gemeenskapsbeoefening tussen die mens en dic dier in Gen. 1:1 2:3 en 2:4-25 en in die res van die Skrif nie. Die mens broclon gemeenskap alleen met ander mense, en met God, wie se beeld hy is. Die mens staan 
bokant die dier en is sy heerser. Onder die diere is daar geen hulp wat by hom pas nie (Gen. 2:18 e.v.) (vel. Vriezen, 1966:133, 139)

\section{SKEPPING EN SONDE}

5.1 Volgens God se eie beoordeling was die skepping goed, selfs baie goed (Gen. 1:31); dit het aan God se doel beantwoord. In die skepping het die mens 'n besondere plek, as verteenwoordiger en beeld van God. Hierdie besondersheid van die mens hou egter tegelykertyd 'n groot gevaar in. Die mens het verwaand geword en dit nie ernstig geneem dat hy net 'n mens is nie, net ' $n$ skepsel, net beeld van God, nie 'n god nie. Genesis 2 en 3 gee in hierdie verband inligting oor die kemnișboom in die tuin van Eden. Die mens wou nie in afhanklikheid van God oor alle dinge, insluitende goed en kwaad, beslis nie. Hy wou dit neutraal en outonoon doen ( $\mathrm{vgl}$. bv. Wallis, 1978:2(11). Hierdie optrede staan in teenstelling tot die beeld van Gind. Daardeur is die mens juis in sy heerskappy oor die natuur aangetas. Hierdie verhouding is skeefgetrek. Die mens se hele lewe en denke word geraak. Daar is 'n groot spanning en teenstelling in die mens en sy bestaan: hy is beeld van God en tog tree hy in stryd daarmee op (vgl. bv. Blocher, 1984:9f); hy is heerser oor die skepping en tog sal hy deur swaarkry 'n bestaan moet maak, want die aarde sal dissels en dorings vir hom voortbring (Gen. 3:17); hy moet sy verstand gebruik, en tog misbruik hy dit. Alles staan nou in die teken van verwagting op herstel, verlossing.

Gen. 2:4-25 en Gen. 3 self bevat reeds verskillende aanduiding van verlossing. Blykhaar le dit ook opgesluit in die naam Jahwe God (Here God), wat hier gebruik word in onderskeiding van die naam God wat in Gen. 1:1-2:3 gebruik word. Die naam Jahwe God wil blykbaar sẽ dat die Skepper (God) dieselfde God is as din God wat later in die geskiedenis in in verbondsverhouding met Israel getree het en veral as Jahwe bekend staan. Hy liet Hom veral aan Mloses as sodanig bekend gemaak (E.ks. 3). Genesis word gekenmerk deur God se verlossende optrede. Hy stuur die mens uit die tuin van Erdnu, maar gen hom klere, toonbeeld van 
beskerming en versorging; Hy red vir. Noag mit die sondvlinel, Hy roepl vir Moses en maak inet hown in nuwe begin (6en. 12:1 3).

So staan die hele Ou Testament in die teken vin verivgyting c. p herstol en bied geen grond vir 'n pessimistiese of uitsiglose blik op die hede of op die toekoms nie. Die Nuwe Testament stel dit nog sterker: dic linlo skepping is now in barensnood oor die koms van Jie Verlosser (Rom. 8:22). God se genade in Hom gee aan alles sin en docl.

\section{DIE TAAK WAT OPGELE IS}

6.1 Die mens het die opdrag van God om konkreet besig te wees en die aarde te onderwerp. Dit moet in in persoonlike verhouding met Hom gedoen word. Hiermee kan hy in sy volle menswees besig wees en hy kan hom ten volle aan die taak wy. Die taak warmee hy moet besig wees, is sinvol, so-ook die voorwerp van sy taak, die skepping of natuur. Hierdie sinvolheid is van krag selfs ondanks die sonde, want dic Middelaar het versoening met die skepper bewerk. So het Hy in lluwo lewe en verwagting gabring.

Daar is 'n universele basis vir hierdie werk van die mens, onder andere vir wetenskapsbeoefening. Die gelowige kan dit saam met mense wat nie nie gelowiges is nie, doen, want die handboek daarvoor is nin die Bybel nie. Dit is nie net Bybelgelowiges wat goeie wetenskap kan booefon nie, net so min as wat net hulle gocie motors kan bou. Dit is omede dir dwingende karakter van die geskape dinge. Donyeweerd (1960: 107 ) pialat van "Stande van sake", wat 'n dinamiese sin-karakter het, dit wil se hulle wys buite en bo hulleself uit na die universele sin-samehang in die tyd,die kreatuurlike wortel-eenheid, en die bo-kreaturrlike oorsprongseenheid van alle sin, 'n heenwysing wat homself in immolike struktuur self uitdruk. Mar hierdie sin-dinamiek beweoy binlle: die onoorskeibare kader van in orde wat deur God gestol is. Die skenping of natuur is die wetenskaplike se voorwerp van ondersoek usook sy onderrigter. lets hiervan kan in die boek Spreuke gesirnl word. Dir: spreuke in die ou Ooste het baie sterk op warneming brutus, ook Bylunlso 
spreuke. Dil gaan in die sprellke om empiriese waarhede, soos algetneen deur mense beleef word, selfs deur ongelowiges. Daar is dan ook groot ooreenkounste tussen Bybelse en buite-Bybelse sprouke. Fukole spreuke lewen volgens sommige eksegete selfs sterk op dic by ongelowige masies (vgl. Murphy, 1983:74).

Ondanks hierdie ooreenkomste en oornames sè die boek Sprenke tog: "Kennis begin met die dien van die Here" $(1: 7)$. Die rede hiervoor is dat die natuur, die aarde, die gesteentes, diere, plante, of wat ookal, nie op sigself staan nie. Die aarde is die werkplek en woonplek van die mens wat in 'n persoonlike verhouding met sy skepper en sy nasste inoet lewe. Hierop gee die Skrif die perspektief. Dit plaas die ondersoeker, die voorwerp van ondersoek en die Skepper in verhouding tot mekaar (vgl. Duvenage, 1982,1985). Die belangrikste divfveer in die Skrifgelowige se lewe is inmers om God te verheerlik. Dic beginsel van ware wetenskap is oorgawe aan God (Helberg, 1981:94; Schulze, 1981).

\section{LITERATUURLYS}

AALDERS, G.CH. 1949. Genesis. Tweede druk. Korte Verklaring der Heilige Schrift. Kampen: Kok.

BLOCHER, H. 1984. In the beginning. Leicester and Illinois : Intervarsity Press.

BURKE, D., ed. 1984. Creation and evolution. Oxford : Intervarsity Press.

CALVYN, J. 1981. Genesis. Grand Rapids: Eerdinans.

DIEMER, J.II. 1963. Natuur en wonder. Amsterdam : Buijten en Schipperheijn. 
DOOYEWEERO, H. 1960. Van Peurseris critische vrighen bij "A New Critique of Theoretical Thought". Philosophia Ri:formati, 25:9i-150).

DU TOIT, S. 1968. Bybel, skepping, evolusic. Johammoubura: Voortrekkerpers.

DUVENAGE, B. 1982. Die lig van die Skrif in die wetenskappe - maak dit 'n verskil? Potchefstroomse Studies in Christelike wetenskap. J3.3. Potchefstroom: PU vir CllO.

DUVENAGE, B. 1985. Christelike wetenskap as Woordgebonde wetenskap. Potchefstroomse Studies in Christelike wetenskap J2.8. Potchefstroom: PU vir CHO.

GISPEN, W.H. 1966. Schepping en paradijs. Verklaring van Genesis 1-3. Kampen : Kok.

GISPEN, W.H. 1974. Genesis Deel 1. Commentaar op het Oude Testament. Kampen : Kok.

HELBERG, J.L.1980. Die Here regeer. Openbaringslyn deur die Ou Testament, Pretoria : N.G. Kerkboekhandel Transvaal.

HELBERG, J.L. 1981. Die beginsel van ware wetenskap is oorgawe aan God. In: Interpretasie en oordeel. Potchefstroomse Studies in Christelike wetenskap. J.1.2.1. Potchefstroom: $\mathrm{PU}$ vir $\mathrm{CHO}, 89-95$.

HELBERG, J.L. 1983. Verklaring en prediking van die Ou Testament. Potchefstroom: Potchefstroomse Teologiese Publikasies.

HELBERG, J.L. 1984. Die integrale karakter van die Ou Testament. In: $U$ lig en $U$ warheid: Potchefstroomse Studies in Christrlike wetenskap. J.1.6.4. Potchefstroom: PU vir CHO, 6-2I.

HOLWERDA, B. 1971. Historia Revelationis Veteris Testamenti. Deel 1. Kampen : Copiëerinrichting v.d. Berg. 
JORDAAN, ELIZABETH FN LOOTS, G.C. 1984. A view of evolution by a christian biologist. Koers, 49.(4): 126.46 .1 .

KI.INE, M. 1970. Genesis. The Now Bible Commentary Revised. Guildford and London : Intervarsity Press.

KROEZE, J.H. 1962. Strijd bij de schepping. Exegetica. Den Haag: Van Keulen.

KROEZE, J.H. 1967. Die tuin van Eden. Pretoria : NG Kerkboekhandel.

KROEZE, J.H. 1974. Adam en Eva. Johannesburg : Boekhandel de Jong.

LEITH, T.H. 1984. Evolution and sovereignty: chance in a purposeful wolld. Koers, 49(4): 408-425.

MANTEN, A.A.1959/84. Het Bijbelse scheppingsverhaal en de natuurwetenschap. Koers, 49(4): 387-407.

MARKS, J.H. 1971. Genesis. The Interpreters's One Volume Commentary on the Bible. London on Glasgow: Collins.

MDUTON, J. 1985. Metodologie van die geesteswetenskappe: basiese begrippe. Pretoria : RGN.

MURPHY, R.F. 1983. Wisclom literature: Job, Proverbs, Ruth, Canticles, Ecclesiastes, and Esther. The Forms of the Old Testament Literature, Vol. 23. Michigan: Ferdinans. begrippe. Pretoria: RGN. OOSTERHOFF, B.J. 1972. Hoe lezen wij Gemesis 2 en 3? Kampen : Kok.

RIDDERBOS, N.HI. 1963. Heschouwingen over Genesis I. I weede druk. Kamprn: Kok.

SANTMIRF, H.P. 1985. The travail of nature. The ambiguous ecological promise of Christian theology. Philadelphia: Fortress Press 
SCHULZE, L.F. 1981. Die beginsel van die wetenskup. Culsyil en ons. Inougurele rede. Wetenskaplike bydraes van die PU vir itho. H.as.

SCHUNCK, K-D. 1979. Die Auffassung des Alten Irestameits von Jrer Natur. Theologische Literaturzeitung, 104:401-412. Juni.

SCHUURMAN, E. 1980. Creation and science. Fundamental questions concerning evolutionism and creationism. RES Theological Forum, 8.2. August.

SIMPSON, C.A. 1952. Genesis. The Interpreter's Bible. New York and Nashville: Abingdon Press.

STECK, O.H. 1978. Alttestamentliche limpulse for eine Theologie der Natur. Theologische Zeitschrift, 34(4):202-211. Juli/August.

VAN SELMS, A. 1967. Genesis. Deel I. Prediking van het Oude Testament. Nijkerk: Callenbach.

VON RAD, G. 1963. Genesis. The Old Testament Iibrary. London: SCM.

VON WEIZSäCKER, C.F, 1974. Die Einheit der Natur. Mlünchen: Carl Hanser.

VRIEZEN, TH.C. 1966. Hoofdlijnen der theologie van het Oude Testament. Derde druk. Wageningen: H. Veenman en Zonen.

WALLIS, G. 1978. Psalm 8 und die etische Fragestellung der modernen Naturwissenschaft. Theologische Zeitschrift, 3.4(4):193.201. Juli/August.

WEISS, P.F.D. 1958. Genesis. Bybel met verklaronde nantekeninge. Kaapstad: Verenigde Protestantse Uitgewers.

WESTERMANN, 1974. Genesis 1-11. Biblischer Kommontar. Noukirchen : Vluyn. 